\title{
BLUETONGUE DISEASE - EPIZOOTIOLOGY SITUATION IN SERBIA IN 2015, DIAGNOSIS AND DIFFERENTIAL DIAGNOSIS
}

Jelena Maksimović Zorić ${ }^{1}$, Vesna Milićević ${ }^{1}$, Ljubiša Veljović ${ }^{1}$, Ivan Pavlović ${ }^{1}$, Vladimir Radosavljević ${ }^{1}$, Miroslav Valčić ${ }^{2}$, Mileva Glišić

${ }^{1}$ Institute of Veterinary Medicine of Serbia, Belgrade, Serbia

${ }^{2}$ Faculty of Veterinary Medicine, Belgrade, Serbia

${ }^{3}$ Ministry of Agriculture and Environmental Protection Veterinary Directorate, Belgrade, Serbia

\section{Abstract}

Bluetongue disease is non-contagious, vector borne, viral disease mainly of sheep but also of other domestic and wild ruminants. Bluetongue virus (BTV) belongs to the family Reoviridae, genus Orbivirus and is characterized by segmented double-stranded RNA. Virus is transmitted from one to another susceptible animal by hematophagous insects of the genus Culicoides. According to official data, between 2002 and 2014, Serbia has belonged to BTV free countries. After that, the first outbreak occurred in August 2014. The last case was reported in December of the same year. During 2015, 74 samples were examined for exclusion of bluetongue disease: 8 in cattle, 65 in sheep and one in goat. In order to detect viral genome, 73 blood samples and one tissue sample were examined by reverse transcription - polymerase chain reaction (RT-PCR). None of tested samples was confirmed to be BTV positive. Following the Instruction of the Ministry of Agriculture and Environmental Protection - Veterinary Directorate, monitoring program for Bluetongue disease in Serbia started from October 2015. The program consists of insect identification and detection of viral genome in Culicoides spp. by RT-PCR assay. Of the 80 samples that were received during the program realization in 2015 , only four, which were collected during late autumn, have contained insects of Culicoides spp. In none of them, BTV was detected. For differential diagnosis, 65 ovine blood samples were examined for the presence of viruses of contagious ecthyma, sheep and goat pox as well as eight bovine blood samples were tested for viruses of bovine viral diarrhea, infectious bovine rhinotracheitis / pustular vulvovaginitis and malignant catarrhal fever. The samples were analyzed using

${ }^{1}$ Corresponding author - Jelena Maksimović Zorić: jeccamaxx@yahoo.com 
molecular methods (PCR and RT-PCR). Only two bovine blood samples gave positive reaction for the presence of bovine viral diarrhea virus.

Key words: bluetongue disease, differential diagnosis

\title{
BOLEST PLAVOG JEZIKA - EPIZOOTIOLOŠKA SITUACIJA U SRBIJI U 2015. GODINI, DIJAGNOSTIKA I DIFERENCIJALNA DIJAGNOSTIKA
}

\author{
Jelena Maksimović Zorić ${ }^{1}$, Vesna Milićević ${ }^{1}$, Ljubiša Veljović ${ }^{1}$, Ivan \\ Pavlović $^{1}$, Vladimir Radosavljević ${ }^{1}$, Miroslav Valčić ${ }^{2}$, Mileva Glišićc \\ ${ }^{1}$ Naučni institute za veterinarstvo Srbije, Beograd Republika Srbija \\ ${ }^{2}$ Faakultet veterinarske medicine, Univerzitet u Beogradu, Republika Srbija \\ 3 Ministarstvo poljoprivrede I zaštite životne sredine, \\ Uprava za veterinu, Beograd, Republika Srbija
}

\section{Kratki sadržaj}

Bolest plavog jezika je nekontagiozno, vektorski uslovljeno virusno oboljenje koje se javlja uglavnom kod ovaca, ali i kod ostalih domaćih i divljih preživara. Virus plavog jezika (Bluetongue Virus - BTV) pripada familiji Reoviridae, rod Orbivirus a karakteriše ga segmentirana dvolančana RNK. Virus među prijemčivim životinjskim vrstama prenosi hematofagni insekt iz roda Culicoides. Prema zvaničnim podacima, Srbija se u periodu između 2002. i 2014.godine smatrala zemljom slobodnom of BTV. Nakon toga, bolest se pojavila prvi put u avgustu 2014. Poslednji slučaj prijavljen je $\mathrm{u}$ decembru iste godine. Tokom 2015. Godine ispitana su 74 uzorka sa ciljem isključivanja bolesti plavog jezika, i to 8 uzoraka poreklom od goveda, 65 od ovaca i jedan od koza. U cilju detekcije virusnog genoma 73 uzorka krvi i jedan uzorak tkiva su ispitani metodom reverzibilne lančane reakcije polimeraze (RT-PCR). Ni jedan od testiranih uzoraka nije bio pozitivan na BTV. U skladu sa Instrukcijom Ministarstvo poljoprivrede i zaštite životne sredine - Uprave za veterinu, u oktobru 2015. godine započet je program monitoringa bolesti plavog jezika u Srbiji. Program podrazumeva identifikaciju insekata i detektovanje genoma virusa kod Culicoides spp. primenom metode RT-PCR. Od ukupno 80 uzoraka koji su primljeni na ispitivanje tokom realizacije programa u 2015. godini, samo četiri uzorka koji su prikupljeni tokom kasne jeseni sadržali su insekte iz roda Culicoides spp. Ni u 
jednom od uzoraka nije detektovan BTV. U svrhu diferencijalne dijagnostike 65 uzoraka ovčije krvi ispitano je na prirustvo virusa kontagioznog ektima, boginja koza i ovaca, a osam uzoraka krvi goveda testirano je na viruse goveđe virusne dijareje, infektivnog goveđeg rihotraheitisa / pustularnog vulvovaginitisa i maligne kataralne groznice. Uzorci su analizirani primenom molekularnih metoda (PCR i RT-PCR). Kod samo dva uzorka krvi goveda ustanovljena je pozitivna reakcija na prisustvo virusa goveđe virusne dijareje.

Ključne reči: bolest plavog jezika, diferencijalna dijagnoza

\section{INTRODUCTION}

Bluetongue disease is non-contagious, vector borne, viral disease that infects mainly sheep but also other domestic and wild ruminants. Bluetongue virus (BTV) belongs to the family Reoviridae, genus Orbivirus. The genome of bluetongue virus is segmented, double-stranded RNA. Up to date, 27 serotypes of bluetongue virus have been discovered (Maan et al., 2012, Jenckel et al., 2015). The virus is transmitted between susceptible animals by hematophagous insects of the genus Culicoides. Only females can transmit the virus. They live around 70 days, and suck blood every 3-4 days (Radojičić et al., 2011). Being the vector borne disease, the presence of vectors is crucial for occurrence of the infection in animals. Seasons with low temperatures, which are free of vectors, influence the epizooty of disease in such way that the disease incidence decreases to zero.

According to official data, Serbia was considered BTV free country during the period $2002-2014^{2}$. This period ended with an outbreak of the disease in August 2014, in the south of the country. Later on, the virus has extended over almost complete territory of Serbia. It was confirmed that the virus that caused the disease belonged to serotype 4 . The last case was reported in December of the same year. During this period, 644 outbreaks have been reported, all of them caused by BTV serotype 4 (BTV4) (Anonymous, 2015, Veljović et al., 2015). Laboratory diagnostic and confirmation were carried out in National Reference Laboratory (NRL) for Bluetongue Disease - Institute of Veterinary Medicine of Serbia (IVMS).

Following the Instruction of the Ministry of Agriculture and Environmental Protection - Veterinary Directorate (Anonymous, 2015), Monitoring program of bluetongue disease has been implemented in October 2015. The program included insect identification and detection of viral genome in Culicoi-

\footnotetext{
${ }^{2}$ http://www.oie.int/wahis_2/public/wahid.php/Diseaseinformation/Immsummary
} 
des spp. by Reverse Transcription - Polymerase Chain Reaction (RT-PCR) and was aimed to determine the vector free periods.

Although clinical signs in sheep are quite typical, there are many other viral diseases with similar manifestation. Clinical signs in cattle are rather rare but can easily be misinterpreted. Therefore, all ill domestic ruminants with facial oedema, erosions of the nasolabial plate, congestion and haemorrhage of mucous membranes, inflammation and necrosis of the skin should be differentially tested for contagious ectyme of sheep, bovine viral diarrhoea, poxvirus infections, viral stomatitis etc.

The aim of this study was to present epizootiological situation of bluetongue disease during 2015 and establishment of differential diagnosis after BTV has been excluded in samples originating from clinically ill ruminants.

\section{MATERIAL AND METHODS}

Laboratory diagnostics of the bluetongue disease was performed at virology department of The Institute of Veterinary Medicine of Serbia, which is a NRL for bluetongue. During 2015, 74 samples originating from sheep, cattle and goat with symptoms of bluetongue were tested by RT-PCR. The majority of tested samples included unclotted blood from ill animals (73 samples). Only one sample originated from a dead goat and was composed of parts of morphologically altered organ (spleen).

Monitoring program for bluetongue disease, issued by the Ministry, prescribes entomology and virology examination of insects. During twelve months (since $1^{\text {st }}$ October 2015 until $30^{\text {th }}$ September 2016), each of twelve Serbian veterinary institutes had to submit to the Institute of Veterinary Medicine of Serbia insects collected on two locations of their respective counties, two times per month (Anonymous, 2015). In the period from 1 October to 31 December 2015,80 pooled insect samples were received. After insect detection by morphological examination, the samples containing Culicoides spp. were examined for the presence of bluetongue virus by RT-PCR.

Detection of bluetongue virus in blood, tissue samples and midges was performed using molecular technique - Reverse Transcription - Polymerase Chain Reaction (RT-PCR), which detects viral nucleic acid. Extraction of the nucleic acid was performed using RNA extraction kit Bioline Isolate RNA Mini Kit (Bioline, UK) in accordance with the manufacturer's instruction. For Reverse Transcription - Polymerase Chain Reaction (RT-PCR) commercial kit Verso 1-Step RT-PCR Kit ReddyMix (Thermo Fisher Scientific Inc., USA) was used. Conventional, nested RT-PCR assay targeting the NS1 gene of BTV was 
performed using primers and thermal protocol referred in the OIE (fr. Office International des Epizooties) Terrestrial Manual 2014, Chapter 2.1.3. ${ }^{3}$

Beside examination on BTV, differential diagnostic assays were performed on all blood samples. Samples originated from sheep ( 65 blood samples) were analyzed for the presence of contagious ectyme and sheep and goat poxviruses, while eight bovine blood samples were analyzed for the detection of bovine viral diarrhea virus, infectious bovine rhinotracheitis / pustular vulvovaginitis and malignant catarrhal fever virus. Polymerase Chain Reaction (PCR) and Reverse Transcription - Polymerase Chain Reaction (RT-PCR) were used for detection of viral genome. Viral DNA was extracted with QIAampDNA Mini Kit (QIAGEN, Germany), and Hot Star Taq PLUS Master Mix Kit (QIAGEN, Germany) was used for PCR. Diagnostic of the contagious ectyme was done following the protocol of Hosamani et al. (2006) where used primers amplify complete sequence for envelope protein (B2L). For the detection of sheeppox and goatpox viruses, PCR protocol for highly conserved region which encodes protein called viral growth factor, was used (Jônatas et al., 2009).

According to recommended differential diagnostic tests, ${ }^{4}$ all bovine blood samples were tested for viruses of bovine viral diarrhea (BVD), infectious bovine rhinotracheitis / pustular vulvovaginitis (IBR/IPV) and malignant catarrhal fever (MCF). For the detection of nucleic acid of those viruses, we used primers and protocols according to Weinstock et al. (2001) for BVD, Deka et al. (2005) for IBR/IPV and Teankumet al. (2006) for MCF.

\section{RESULTS AND DISCUSSION}

Analysis of 73 samples of unclotted blood as well as 1 tissue sample for the presence of bluetongue virus gave negative result, what leads to a conclusion that during 2015 there were no laboratory confirmed outbreak of bluetongue disease. Those results represent combination of many biotic and abiotic factors, as well as climatic changes that led to the completion of outbreak of bluetongue disease during the winter 2014/2015.

The process of spreading of BTV and development of epizooty highly depends on vectors. For the transmission of the virus, competent vectors ${ }^{5}$, viremic and susceptible animals are necessary. Thus, efficient transmission on the location with viremic animals requires presence of specific species of

\footnotetext{
${ }^{3} \mathrm{http} / /$ www.oie.int/fileadmin/Home/eng/Health_standards/tahm/2.01.03_BLUETONGUE.pdf ${ }^{4} \mathrm{http}: / /$ www.oie.int/fileadmin/Home/eng/Animal_Health_in_the_World/docs/pdf/Disease_cards/BLUETONGUE.pdf ${ }^{5}$ Vector competence defines ability of a vector to become infected and to have a possibility to replicate and disseminate a virus
} 
Culicoides, which can transmit the virus. Until now, four species of Culicoides in which BTV can propagate have been identified in the territory of Serbia: Culicoides pulicaris, C. nubeculosus, C. obsoletus and C. parroti (Pavlović Ivan, 2015). Besides the necessity of the presence of competent vector species, the vectors during their lifetime have to be fed on viremic animal and survive extrinsic incubation period (which depends on outside temperature, humidity, etc), whilst virus multiplies in the gut of the insect. To spread the infection, infected midges have to bite susceptible, naïve animal and to excrete sufficient amount of the virus into its blood. Many physiological barriers may act to limit or constrain dissemination of the virus throughout the insect's organs and thus prevent transmission. It is important to emphasize that only Culicoides females suckle blood, and that they live probably 10-20 days, exceptionally longer (between 44 and 90days) (Mellor et al., 2000).

With the arrival of wintertime, conditions for reproduction of insects become unfavorable. Among other weather conditions that can influence vectorial capacity of Culicoides spp., the temperature is the most important one. It affects the number of generations that can arise during one season and the population size. Temperature influences the virus infection/replication in the bodies of adult midges. For few vector species, it was proved that the complete inhibition of virus replication occurs when ambient temperature decreases below $15^{\circ} \mathrm{C}$ (Mullens et al., 1995). Contrary to that, infection rate and speed of virus replication grows at higher temperatures, but the life of midges shortens (Mullens et al., 1995). Increase of precipitation during summer season favors their reproduction.

Beside the competent vector, viremic animal is another essential factor in this equation with many variables. The duration of viremia in bluetongue disease is variable. It lasts from 3 to 300 days (Radojičić et al., 2011). Longer duration of viremia implies higher possibility for the occurrence of new disease outbreaks after winter. It is well known that among susceptible species the longest duration of viremia is recorded in cattle - maximum 300 days (Radojičić et al., 2011). Therefore, this species is considered most responsible for overwintering of the virus and new outbreaks after long period with unfavorable climatic conditions.

Having in mind the aforementioned facts, it is clear that the process of transmission and overwintering of the virus can fail in many points.

Although the predictions from the beginning of 2015 suggested that new outbreaks of bluetongue will appear in our country again (Veljović et al., 2015), it became obvious that climatic factors were not favorable for the development of Culicoides spp. Most probably, cold wave with temperatures below $-10^{\circ} \mathrm{C}$ 
during December 2014 and January $2015^{6}$ caused disappearance of adult competent vectors and termination of reproductive cycle. On the other hand, long and very hot summer in 2015, with six hot waves and average precipitation ${ }^{6}$, reduced the number of newly borne Culicoides spp. Moreover, animal population that is partially seroconverted makes unfavorable circumstances for new epizooty of BTV serotype 4.

Many surrounding countries encountered outbreaks of bluetongue during 2015 (Hungary, Romania, Macedonia, Albania, Bosnia and Herzegovina and Croatia) $)^{7}$. Only Hungary and Croatia faced the outbreaks that happened close to the border with Serbia, but transmission across the border has not been confirmed.

Monitoring program that has begun in October 2015 is aimed at examining and establishing local presence of Culicoides spp. and defining seasons throughout the year that are free of vectors. To the end of 2015,80 pooled samples of insects have been collected and delivered to the IVMS. Among them, only four, which were collected during November, contained insects of Culicoides spp. (C.obsoletus). As RT-PCR and nested PCR for detection of NS1 gene ${ }^{8}$ gave negative results it could be concluded that midges had not been infected with bluetongue virus.

Differential diagnostic assays were performed on all 73 animal blood samples. Sixty-five ovine samples have been examined for viruses of contagious ectyme, and sheep and goat pox. All samples gave negative results for the presence of genome segment that encodes synthesis of viral growth factor of sheep and goat poxviruses. According to the official data, the virus circulated in neighboring countries between 2013 and 2015 (Bulgaria - 2013 and Greece 2013-2015) ${ }^{9}$, but not in close proximity to the Serbian border. As this is highly contagious disease that cause high morbidity (around 75\%) and mortality (around 50\%) in naive populations (Radojičić et al., 2011), it was expected that these analyses would give negative result.

Contagious ectyme is widespread across our territory. During 2014, six positive samples (animals) were detected at virology department of The Institute of Veterinary Medicine of Serbia. Out of 65 blood samples tested during 2015, not even one gave positive reaction. Genome of parapoxvirus has not been detected in blood, though it was expected because of its presence in ovine population during 2014. For a more accurate diagnosis, the sampling and sam-

\footnotetext{
${ }^{6}$ http://www.hidmet.gov.rs/ciril/meteorologija/klimatologija_produkti.php ${ }^{7}$ http://www.oie.int/wahis_2/public/wahid.php/Diseaseinformation/Immsummary ${ }^{8} \mathrm{http} / / /$ www.oie.int/fileadmin/Home/eng/Health_standards/tahm/2.01.03_BLUETONGUE.pdf ${ }^{9}$ http://www.oie.int/wahis_2/public/wahid.php/Diseaseinformation/Immsummary
} 
ple submission for laboratory diagnostics should be done during the clinical phase of the disease. As soon as the first symptoms with skin changes appear, the sample of choice is a fluid from the vesicles, and later on a scab. Although unclotted blood is the best sample for BTV detection (because of quite long viremia), in case of poxvirus infections, virus is present in blood for short period of time and therefore this type of sample is not reliable particularly if taken after viremic stage of the disease.

After primary and secondary viremia, the highest amount of the virus is present in skin pustules and in scabs that arise after eruption of pustules (Baxby D., 1996). Thus, these are the preferable samples for laboratory testing when speaking of animals in this phase of the disease. Negative results in our testing were probably due to the fact that blood is not enough suitable sample for poxvirus PCR analysis.

Bovine samples collected for the detection of bluetongue virus were differentially examined for viruses of bovine viral diarrhea, infective bovine rinotracheitis / pustular vulvovaginitis and malignant catarrhal fever. Among these viruses, only viral genome of bovine viral diarrhea virus was detected. Two samples positive for bovine viral diarrhea virus originated from cattle from the settlements of Gaj, municipality Kovin, and Dobrica, municipality of Alibunar. Such result was expected having in mind unfavorable epizootiological situation in whole country.

\section{CONCLUSION}

Opposite to predictions, bluetongue disease was not confirmed in NRL for bluetongue during 2015. Which combination of factors drive up to the preferable epizootiology situation is still an open question. Thank to it, epizootiological situation is better now than in the last year (2014). The monitoring program has been carried out until the autumn 2016, and its results should help us to deal with new potential epizooties. In addition, a program of vaccination of ruminants in regions where outbreaks occurred and in regions where combination of abiotic, biotic and climatic factors is favorable for bluetongue disease was started at the end of 2015. Killed vaccine should prevent infection of ruminants with BTV serotype 4 and decrease the probability of new outbreaks. Differential diagnostic assays served for exclusion and confirmation of other viral diseases with similar symptoms. In order to obtain better and more reliable results, appropriate samples (beside blood) from ill animals should be collected and used for laboratory examination. 


\section{ACKNOWLEDGEMENTS}

This work was supported by the Ministry of Education, Science and Technological Development (grant numbers TR31084, TR 37015) and the Ministry of Agriculture and Environmental Protection -Veterinary Directorate, Republic of Serbia

\section{REFERENCES}

1. Anonymous: Ministarstvo poljoprivrede i zaštite životne sredine, Uprava za veterinu, 2015: Uputstvo o načinu sprovođenja entomoloških i virusoloških ispitivanja u cilju monitoringa i nadzora bolesti plavog jezika na području Republike Srbije

2. Baxby D.: Poxviruses. Medical Microbiology. 4th edition, editor Baron S., Galveston (TX): University of Texas Medical Branch at Galveston; 1996. http://www.ncbi.nlm.nih.gov/books/NBK8364/?report=printable

3. Deka D., Ramneek, Maiti N. K. and Oberoi M. S.: Detection of bovine herpesvirus-1 infection in breeding bull semen by virus isolation and polymerase chain reaction. Rev. sci. tech. Off. int. Epiz., 24, 3, 1085-1094, 2005.

4. Hosamani M., Bhanuprakash V., Scagliarini A., Singh R.K.: Comparative sequence analysis of major envelope protein gene (B2L) of Indian orf viruses isolated from sheep and goats. Veterinary Microbiology, 116, 317-324, 2006.

5. Jenckel M., Bréard E., Schulz C., Sailleau C., Viarouge C., Hoffmann B., Höper D., Beer M., Zientara S. 2015. Complete coding genome sequence of putative novel bluetongue virus serotype 27. Genome Announcement 3, 2:e0016-15. doi:10.1128/genomeA.00016-15.

6. Jônatas A., Lima L., Assis F., Alves P., Silva-Fernandes A., Cota M., Ferreira V., Campos R., Mazur C., Lobato Z., Trindade G. and Kroon E.: Nested-multiplex PCR detection of Orthopoxvirus and Parapoxvirus directly from exanthematic clinical samples. Virology Journal, 6, 140, 2009. http:// www.virologyj.com/content/6/1/140

7. Maan N. S., Maan S., Belaganahalli M. N., Ostlund E. N., Johnson D. J., et al. (2012) Identification and differentiation of the twenty-six bluetongue virus serotypes by RT-PCR amplification of the serotype-specific genome segment 2. PLoSONE 7, 2: e32601. doi:10.1371/journal.pone.0032601

8. Mellor P. S., Boorman J., and Baylis M.: Culicoides biting midges: their role as arbovirus vectors. Annu. Rev. Entomol. 45, 307-340, 2000.

9. Mullens B. A., Tabachnick W. J., Holbrook F.R., Thompson L. H.: Effects of 
temperature on virogenesis of bluetongue virus serotype 11 in Culicoides variipennis sonorensis. Med. Vet. Entomol. 9, 71-76, 1995.

10. Pavlović I.: Vektori plavog jezika. U: Zbornik radova XXVI Savetovanja dezinfekcija, dezinsekcija i deratizacija - jedan svet jedno zdravlje - sa međunarodnim učešćem, 28-31.Maj, Novi Bečej, 2015., 110-122.

11. Radojičić S., Valčić M., Đuričić B.: Infektivne bolesti. Drugi deo - Bolesti virusne etiologije: Familija Reoviridae, Beograd, 2011

12. Teankam K., Tantilertcharoen R., Boonserm T., Suadsong S., Banlunara W.: Malignant catarrhal fever in swamp buffaloes (Bubalus bubalis): a retrospective pathological study of outbreaks in Thailand. Thai Journal of Veterinary Medicine. 36, 1, 19-30, 2006.

13. Veljović Lj., Milićević V., Maksimović Zorić J., Ostojić S., Radosavljević V.: Epizootija bolesti plavog jezika u Srbiji tokom 2014. godine i prognoze za 2015. godinu. U: Zbornik kratkih sadržaja, XVII Simpozijum epizootiologa i epidemiologa.. 23. - 24. april, Niš, 2015, 62-63.

14. Weinstock D., Bhudevi B., and Castro A.: Single-tube single-enzyme reverse transcriptase PCR assay for detection of bovine viral diarrhea virus in pooled bovine serum. Journal of Clinical Microbiology, 343-346, 2001.

Primljeno: 01.07.2016.

Odobreno: 15.09.2016. 